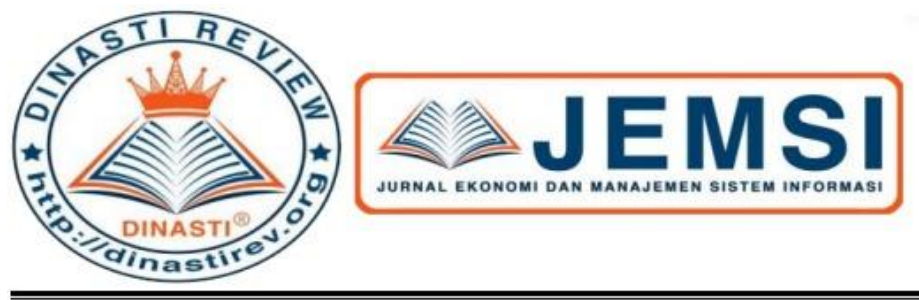

+62 878-9658-6407

087896586407 ()

https://dinastirev.org/JEMSI (-)

editor@dinastirev.org (G.

\title{
PERAN SISTEM INFORMASI TERHADAP OPERASONAL RETAIL
}

\section{Refina Gita Anjani}

Universitas Mercu Buana, Jakarta

\begin{tabular}{|c|c|}
\hline $\begin{array}{l}\text { ARTICLE INFORMATION } \\
\text { Received: } 24 \text { Agustus } 2019 \\
\text { Revised: } 31 \text { Agustus } 2019 \\
\text { Issued: } 5 \text { September } 2019\end{array}$ & $\begin{array}{l}\text { Abstrak: Bisnis ritel merupakan aktivitas bisnis yang } \\
\text { melibatkan penjualan barang dan jasa secara langsung } \\
\text { kepada konsumen akhir. Pada perkembangannya, kini } \\
\text { bisnis ritel di Indonesia mulai bertransformasi dari } \\
\text { bisnis ritel tradisional menuju bisnis ritel modern. } \\
\text { Perkembangan bisnis ritel modern di Indonesia sudah } \\
\text { semakin menjamur di hampir seluruh wilayah } \\
\text { Indonesia. Hal tersebut dapat terlihat dari banyaknya } \\
\text { toko retailer modern yang membuka cabang di } \\
\text { berbagai wilayah di Indonesia. Dalam perdagangan } \\
\text { eceran atau ritel dimana arus data barang dagangan } \\
\text { dan uang berputar sangat cepat diperlukan } \\
\text { pengendalian dan pengawasan yang baik. Salah satu } \\
\text { bentuk pengendalian dan pengawasan tersebut ada } \\
\text { dibutuhkanlah dengan melakukan pencatatan data yang } \\
\text { tertib dan teratur, serta penyuguhan informasi dalam } \\
\text { bentuk sistem pelaporan yang tepat waktu dan akurat } \\
\text { sehingga memberikan manfaat yang optimal bagi } \\
\text { setiap keputusan yang akan diambil. Sistem Informasi } \\
\text { Ritel (SIM Ritel) adalah suatu sistem informasi yang } \\
\text { dikembangkan dengan menggunakan pendekatan yang } \\
\text { berbasis pada pemanfaatan teknologi terpadu peralatan } \\
\text { sistem mekanisasi pengolah data sebagai penyedia } \\
\text { informasi untuk menunjang semua aspek kegiatan } \\
\text { yang berhubungan dengan operasional, manajemen, } \\
\text { analisis maupun dalam hal pembuatan keputusan. } \\
\text { Kata Kunci: Sistem Informasi, Ritel, Sistem } \\
\text { Informasi Ritel }\end{array}$ \\
\hline
\end{tabular}

\section{PENDAHULUAN}

Artikel ini berkenaan tentang peran dari sistem infomasi terhadap retail. Ketika tren teknologi bisnis berevolusi, bisnis retail berpeluang untuk memberikan pengalaman pelanggan yang berbeda. Sayangnya, dalam era digital ini, kecepatan dalam mengantarkan pembaruan di bisnis retail semakin menjadi penentu kekuatan daya saing di pasar. Dan ini artinya, sistem informasi bisnis retail harus cepat dapat beradaptasi dengan perubahan. 
Transformasi bisnis digital dapat membantu bisnis retail melakukan inovasi sehingga mereka dapat menciptakan momen luar biasa bersama pelanggan. Tidak mengherankan, transformasi digital terus memperlebar jurang antara pemimpin pasar dengan mereka yang lambat dalam beradapatasi dengan perubahan. Pada tahun 2018, ada banyak sekali hal yang harus dilakukan oleh para pelaku bisnis retail untuk dapat bertahan di era sekarang yaitu revolusi industry 4.0. salah satu hal yang dapat membantu adalah sistem informasi pada retail.

Bisnis ritel merupakan aktivitas bisnis yang melibatkan penjualan barang dan jasa secara langsung kepada konsumen akhir. Pada perkembangannya, kini bisnis ritel di Indonesia mulai bertransformasi dari bisnis ritel tradisional menuju bisnis ritel modern. Perkembangan bisnis ritel modern di Indonesia sudah semakin menjamur di hampir seluruh wilayah Indonesia. Hal tersebut dapat terlihat dari banyaknya toko retailer modern yang membuka cabang di berbagai wilayah di Indonesia.

\section{Faktor Penting Untuk Sistem Informasi Bisnis Retail di Era Digital}

Kita dapat melihat contoh perusahaan gojek yang dapat dengan cepat menguasai pasar. Kini gojek tidak hanya untuk kebutuhan transportasi saja, akan tetapi bisa untuk membeli kebutuhan sehari-hari di toko retail seperti alfamart dan indomaret. Dan kita dapat melihat juga, Blue Bird sebagai perusahaan yang menguasai pasar taksi di Indonesia semakin tertekan. Dan akhirnya, mau tidak mau blue bird membuat aplikasi juga, dan bahkan membeli saham gojek.

1) Investasi infrastruktur untuk mengikuti laju perkembangan teknologi digital.

Mau tidak mau, investasi infrastruktur harus dilakukan oleh setiap bisnis retail untuk dapat mengikut perkembangan teknologi digital yang sangat pesat. Ini untuk mengimbangi pesaing dan untuk beradaptasi dengan perilaku konsumen. Untuk meningkatkan sistem informasi, bisnis retail perlu meningkatkan infrastruktur teknologi informasi. Bahwa, di era digital sekarang ini, kecepatan dalam berinovasi menjadi faktor penentu. Dengan infrastruktur teknologi informasi yang tepat dan sesuai kebutuhan, sistem informasi bisnis retail selalu dapat mengadopsi perubahan dengan cepat. Dengan infrastruktur teknologi informasi yang kuat, bisnis retail dapat terus berinovasi dan terhindar dari kelumpuhan IT atau downtime. Downtime merupakan salah satu masalah yang harus dapat di mitigasi. Jika tidak, reputasi bisnis dapat turun dan perusahaan harus mengeluarkan biaya yang lebih banyak lagi untuk memulihkan dan mempertahankan pelanggan.

2) Penggunaan teknologi cloud

Ini dapat mendorong pengalaman pelanggan yang berbeda. Karena, dengan menggunakan teknologi cloud, sistem informasi bisnis retail lebih mungkin untuk dapat berkembang dengan cepat. Selain itu, penggunaan cloud lebih efisien untuk skala tertentu. Hanya saja, dalam hal ini, kami perlu mengingatkan agar sistem informasi bisnis retail dapat menjaga tagihan cloud dari lonjakan. Dalam transformasi digital, akan selalu banyak pengujian yang dilakukan. Ini dapat mengganggu operasional jika tidak menggunakan infrastruktur teknologi informasi yang sesuai tuntutan tersebut. Mulai lah untuk bermitra dengan para konsultan teknologi informasi yang berpengalaman dalam manajemen aplikasi dan infrastruktur cloud hybrid.

3) Prioritaskan keamanan untuk lebih melindungi informasi pelanggan

Pelanggaran data merupakan isu yang paling dominan di bisnis retail. Beberapa kasus pencurian data pelanggan telah terjadi di seluruh dunia. Dalam hal ini, sistem informasi bisnis retail harus menerapkan strategi dan praktik terbaik dalam menjaga data konsumen. 
Biaya pelanggaran data cukup besar, dan dapat meruntuhkan kepercayaan pelanggan. Selain itu, bisnis dapat berhadapan dengan tuntutan yang serius. Oleh karena itu, keamanan sistem informasi bisnis retail harus dapat melindungi informasi pelanggan.

4) Investasi teknologi di toko fisik

Hal ini dapat meningkatkan dan merampingkan proses transaksi. Dengan cara ini, bisnis retail dapat mengurangi antrian di kasir. Misal, dengan meanfaatkan teknologi fintech untuk pembayaran digital. Bahkan, Amazon telah membuat sebuah toko retail fisik yang tidak memerlukan kasir. Mengurangi antrian di kasir dapat menjadi prioritas utama dalam meningkatkan pengalaman pelanggan pengunjung toko fisik. Selain itu, manajemen stok secara real-time dan dapat terhubung ke pemasok serta melakukan order secara otomatis dapat menjadi pertimbangan dalam meningkatkan efisiensi dan kecepatan. Perlu diperhatikan bahwa perlambatan jaringan dapat mengganggu operasional bisnis retail, baik di back-office maupun di kasir. Inilah pentingnya untuk memiliki infrastruktur teknologi informasi yang kuat bagi bisnis retail.

5) Saluran digital merupakan omni-channel baru

Kepuasan pelanggan merupakan modal utama bisnis retail untuk bertahan. Di era digital sekarang ini, media sosial dapat menambah kedekatan antara bisnis dengan pelanggan. Akan tetapi, media sosial dapat menjadi faktor yang meruntuhkan reputasi bisnis.

Misal, ada konsumen yang kecewa, baik karena produk maupun layanan di toko retail Anda. Konsumen tersebut dapat menceritakan panjang lebar di jaringan media sosial. Dan ini jika terjadi viral, maka dapat memukul reputasi bisnis anda. Selain itu, banyak platform social yang dapat dimanfaatkan untuk mendukung penjualan anda. Perlu anda ketahui bahwa transformasi digital membutuhkan strategi digital marketing yang tepat untuk mengimbangi bisnis anda di tengah kancah persaingan. Percayalah, pesaingpesaing anda juga lakukan hal yang sama, dan anda harus bisa lebih baik dari pesaingpesaing bisnis yang ada.

Lalu juga Tetap Awasi Lingkungan Digital Anda. Di dunia digital saat ini, pengecer multi- saluran harus memuaskan pelanggan mereka dengan pengalaman merek dan pengalaman pengguna yang luar biasa. Dengan bermitra pada konsultan teknologi informasi dan konsultan pemasaran digital, bisnis retail anda dapat melangkah lebih maju dari pada yang lain.

\section{KAJIAN PUSTAKA}

Meskipun perekonomian dan perindustrian nasional kini dihadapkan kepada dampak krisis ekonomi global, namun bisnis ritel di Indonesia tidak terkendala bahkan masih menunjukkan pertumbuhan yang pesat. Hal itu disebabkan potensi pasar di Indonesia masih cukup besar serta menguatnya usaha kelas menengah dan kecil, telah menambah banyaknya kelompok masyarakat berpenghasilan menengah-atas yang memiliki gaya hidup belanja di ritel modern. (Areef, 2010).

Pada tahun 2010, industri ritel modern di Indonesia mengalami pertumbuhan yang sangat pesat. Asosiasi Pengusaha Ritel Indonesia (Aprindo) memperkirakan total belanja ritel tahun ini akan mencapai Rp 100 triliun, dimana Rp 65 triliun merupakan belanja consumer goods. Dari jumlah belanja ini, hypermarket mengambil bagian 35 persen, minimarket dan supermarket 45 persen, dan ritel tradisional 20 persen. Persentase besar yang dimiliki ritel-ritel modern tersebut disebabkan karena adanya tuntutan konsumen terhadap kualitas produk, harga, kecepatan respon, ketepatan pengiriman serta ketersediaan barang di pasaran semakin tinggi. (Hapsarini, 2010). 
Usaha setiap ritel akan pemenuhan tuntutan konsumen itu tidak lepas dari penerapan suatu manajemen rantai pasok (supply chain management) yang baik. Rantai pasok itu dapat terbentuk dari jaringan perusahaan-perusahaan yang secara bersama-sama bekerja untuk menciptakan dan menghantarkan suatu produk ke tangan pemakai akhir. Perusahaanperusahaan tersebut biasanya termasuk pemasok, pabrik, distributor, toko atau ritel, serta perusahaan pendukung seperti perusahaan jasa logistic.

Manajemen rantai pasok (supply chain management) adalah metode, alat, atau pendekatan pengelolaan rantai pasok yang tidak hanya berorientasi pada urusan internal perusahaan tetapi juga urusan eksternal yang menyangkut hubungan dengan perusahaanperusahaan partner. Inti dari pengelolaan rantai pasok ini adalah untuk memuaskan konsumen akhir, bekerja sama untuk membuat produk yang murah, mengirimkannya tepat waktu, dan dengan kualitas yang bagus. Kurangnya kerjasama seringkali menimbulkan kesalahan informasi yang akibatnya adalah variasi permintaan dan kurangnya kepercayaan yang terjadi pada jaringan supply chain.

Dalam supply chain terdapat 3 macam aliran yang harus dikelola. Yang pertama aliran barang yang mengalir dari hulu ke hilir, contohnya aliran bahan baku dari pemasok ke manufaktur. Kedua, aliran uang dan sejenisnya yang mengalir dari hilir ke hulu. Ketiga, aliran informasi yang bisa terjadi dari hulu ke hilir ataupun sebaliknya. Informasi tentang persediaan produk yang masih ada di masing-masing ritel sering dibutuhkan oleh distributor maupun pabrik. Dalam hal ini ritel juga memberikan peranan penting dalam penentu keberhasilan suatu manajemen rantai pasok.

Karakteristik dasar retail dapat digunakan sebagai dasar dalam mengelompokkan jenis retail. Karakteristik dasar yaitu:

1) Jenis barang yang dijual (Type of merchandise).

Retail dapat dibedakan berdasarkan jenis produk yang dijualnya. Sebagai contoh retail yang menjual produk olahraga biasanya toko peralatan olahraga. Jenis retail ini selanjutnya dapat dibagi lagi menjadi toko peralatan olahraga untuk anak-anak, wanita, maupun pria. Selain itu juga dapat dibagi menurut jenis olahraga itu sendiri seperti basket, golf, sepak bola, pencak silat, karate, taekwondo, dan jujitsu.

2) Perbedaan keanekaragaman barang yang dijual (Variety and Assortment).

Yang dimaksud dengan perbedaan barang yang dijual adalah jumlah kategori barang yang ditawarkan retail. Sedangkan keanekaragaman barang yang dijual adalah jumlah barang yang berbeda dalam satu kategori barang. Tiap barang yang berbeda disebut dengan istilah unit penyimpanan persediaan. Pada retail jenis ini, produk-produk yang dijual meliputi beragam jenis dan tidak terbatas pada satu jenis saja.

3) Tingkat layanan konsumen (Customer Service)

Retail juga berbeda dalam hal jasa yang mereka tawarkan kepada konsumen. Contohnya, toko sepeda menawarkan bantuan dalam memilihkan sepeda, menyesuaikan spesifikasi sesuai keinganan pembeli, dan memperbaiki sepeda.

4) Harga barang (Price cost trade off)

Pada peretail dapat dibedakan dari tingkat harga dan biaya produk yang dikenakannnya. Sebagai contoh, department store dan toko diskon. Toko diskon memilik perbedaan dalam menetapkan harga produk-produk yang dijual. Departement store, menetapkan tingkat harga yang lebih tinggi karena menanggung biaya yang lebih tinggi dalam persediaan beberapa produk fashionable. 


\section{METODE PENELITIAN}

Artikel ini menggunakan metode Studi Pustaka. Metode pada artikel ini adalah menganalisis dan membandingkan antara teori dan implementasi peran sistem informasi pada operasional Retail store.

\section{HASIL DAN PEMBAHASAN}

Dalam memilih retail store, pembeli mempertimbangkan banyak hal. Faktor yang diperhatikan adalah yang berkaitan dengan kebutuhan ekonominya. Di lain pihak kebutuhan emosional (seperti gengsi) juga kadangkala mempengaruhi pilihannya.

Suatu jaringan persediaan yang efisien mempunyai dua manfaat untuk pelanggan yaitu:

a) Untuk memenuhi kepentingan dalam pemenuhan persediaan barang dagangan yang mempunyai sifat cepat habis, dan

b) Memenuhi kebutuhan pelanggan terhadap pilihan barang dagangan sesuai dengan "apa" yang pelanggan inginkan, serta "dimana" mereka menginginkan. Manfaat ini akan dirasakan pula pada penjualan yang lebih besar, perputaran persediaan yang lebih tinggi, dan berdampak pula terhadap penentuan dlam menetapkan mark down untuk bisnis ritel.

Faktor-faktor ekonomi yang relevan dalam memilih retail store antara lain meliputi:

1) Harga

Ada retail store yang memasang harga mati seperti supermarket dan departement store) dan ada pula yang menetapkan harga fleksibel atau dapat ditawar (seperti discount store).

2) Kemudahan

Kemudahan parkir, bisa cepat pergi setelah membayar, dan mudah mencari barang yang diinginkan (meliputi proses menemukan, membandingkan, dan memilih).

3) Kualitas produk yang ditawarkan.

4) Bantuan wiraniaga.

Apakah harus swalayan, membantu secara pasif, atau membantu secara aktif.

5) Reputasi

Kejujuran dan kewajaran dalam jual beli

6) Nilai yang ditawarkan

Yaitu perbedaan total customer value dan total customer cost. Total customer value adalah sekumpulan manfaat yang diharapkan pelanggan dari produk dan jasa, meliputi product value (misalnya keandalan, daya tahan/keawetan, unjuk kerja), service value (penyerahan barang, pelatihan, instalasi, perawatan, reparasi), personnel value (kompeten, responsif, empati, dapat dipercaya), dan image value (citra perusahaan). Sedangkan total customer cost terdiri dari harga yang dibayarkan, biaya waktu, biaya tenaga, dan biaya psikis.

7) Jasa-jasa khusus yang ditawarkan.

Pengiriman barang gratis, pembelian kredit dan bisa mengembalikan atau menukar barang yang sudah dibeli.

\section{Sistem Informasi Manajemen}

Dalam perdagangan eceran atau ritel dimana arus data barang dagangan dan uang berputar sangat cepat diperlukan pengendalian dan pengawasan yang baik. Salah satu bentuk pengendalian dan pengawasan tersebut ada dibutuhkanlah dengan melakukan pencatatan data yang tertib dan teratur, serta penyuguhan informasi dalam bentuk sistem pelaporan yang tepat waktu dan akurat sehingga memberikan manfaat yang optimal bagi setiap keputusan yang 
akan diambil. Sistem Informasi Ritel (SIM Ritel) adalah suatu sistem informasi yang dikembangkan dengan menggunakan pendekatan yang berbasis pada pemanfaatan teknologi terpadu peralatan sistem mekanisasi pengolah data sebagai penyedia informasi untuk menunjang semua aspek kegiatan yang berhubungan dengan operasional, manajemen, analisis maupun dalam hal pembuatan keputusan.

Mengelola manajemen bisnis ritel yang beroperasi secara global merupakan sebuah tantangan, sebab unit yang dijual bervariasi pada tiap negara, demikian juga pasar asing pasti mempunyai karakteristik yang berbeda dengan pasar domestik. Hal ini meningkatkan kompleksitas dalam pemeliharaan dan penyediaan barang dagangan sesui kebutuhan yang terbagi dalam divisi barang dagangan. Untuk tujuan ini, biasanya dibutuhkan investasi pada sistem jika mengharapkan laju mengharapkan laju pertumbuhan penjualan akan terus meningkat.

Secara umum struktur SIM Ritel tidak berbeda dengan Sistem Informasi Manajemen lainnya, meliputi :

1) Tingkatan informasi untuk proses transaksi, dalam hal ini fungsinya adalah sebagai inquiry response. Tingkatan ini biasanya menjadi tanggung jawab dari staff atau clerk.

2) Tingkatan informasi untuk perencanaan operasional, pengendalian dan pengambilan keputusan. Informasi yang berkaitan dengan kegiatan operasional setiap harinya dibutuhkan oleh Lower Management yang berada pada tingkatan ini untuk pengambilan keputusan.

3) Tingkatan informasi untuk perencanaan taktis dan pengambilan keputusan. Pada tingkatan ini Middle Management membutuhkan informasi yang datangnya dari tingkat perencanaan operasional maupun informasi dari luar lingkungan perusahan seperti informasi tentang pesaing. Informasi tersebut nantinya akan menjadi dasar pembuatan rencana taktis perusahaan. Contohnya pembuatan anggaran maupun pengambilan keputusan seperti penentuan jenis dan harga barang.

4) Tingkatan informasi untuk perencanaan strategik, kebijakan dan pengambilan keputusan. Tujuan dan arah perusahaan ditentukan oleh Top Management. Karena itu informasi yang berkaitan dengan kinerja perusahaan dan keadaan lingkungan luar perusahaan perlu dimiliki oleh tingkat ini demi kemajuan perusahaan.

Lebih jelasnya struktur tingkatan Sistem Informasi ritel dapat dilihat sebagai berikut :

a. IS for transaction processing and inquiry response

b. IS for operational planning control and decision making

c. IS for tactical planning and decision making

d. IS for strategic and policy planning and decision making

e. Top Management

f. Middle Management

g. Lower Management

h. Staff / Clerk. Elemen-Elemen SIM Ritel

Untuk membangun suatu Sistem Informasi Ritel dibutuhkan beberapa elemen, meliputi :
a. Perangkat Keras
b. Perangkat Lunak
c. Database
d. Manual Procedur
e. Petugas pengoperasian sistem 
Elemen-elemen di atas kemudian tersusun ke dalam suatu sistem konfigurasi, yang merupakan rangkaian perangkat keras dan lunak yang dirancang serta disusun secara terpadu dalam suatu sistem, sehingga sistem tersebut dapat berjalan sesuai yang dibutuhkan.

\section{Tahapan Pengembangan Sistem Informasi}

Berikut beberapa tahapan pengembangan system informasi:

a) Menentukan jenis dan skala usaha

b) Menentukan lingkup dan prioritas sistem informasi yang dibutuhkan

c) Menentukan besarnya volume data yang akan diproses

d) Menentukan besarnya frekuensi transaksi data yang akan diproses

e) Menentukan jenis dan jumlah peralatan mekanisasi yang dibutuhkan

f) Menentukan format struktur database

g) Menentukan jenis dan format laporan / informasi yang dibutuhkan

h) Menentukan jadwal pengembangan program-program aplikasi sim

i) Menentukan jadwal pelatihan dan implementasi

\section{Evaluasi}

Dalam Sistem Informasi Ritel identifikasi barang memegang peran yang sangat penting. Mulai dari Jenis barangnya, merk barang, produsen, sampai harga. Untuk memudahkan identifikasi tersebut, biasanya setiap barang dibuat kodenya sesuai dengan kelompok jenisnya.

Laporan Tingkat Manajemen pada Perusahaan Retail

1) Informasi data processing untuk manajemen tingkat operasional (Laporan Penjualan per Kasir)

2) Informasi bagi tingkat perencanaan taktis (Laporan Penjualan per Item / Kelompok Barang)

3) Informasi bagi tingkat perencanaan dan pengendalian strategis (Laporan Perhitungan Laba / Rugi)

\section{KESIMPULAN DAN SARAN}

Berdasarkan uraian diatas dapatlah kita mengambil kesimpulan bahwa sudah layaknyalah perusahaan memiliki Strategi Pemasarannya sendiri sebelum mereka menjalankan ataupun memasarkan produk/jasanya.

Strategi pemasaran yang dibuat hendaknya haruslah mempertimbangkan situasi dan keadaan perusahaan baik keadaan intern perusahaan itu sendiri atau lingkungan mikro perusahaan, maupun keadaan ekstern perusahaan atau yang dikenal dengan lingkungan makro perusahaan.

Perusahaan yang berjaya dan mampu mempertahankan serta meningkatkan lagi penjulannya ditengah-tengah pesaingnya adalah perusahaan yang telah berhasil menetapkan strategi pemasarannya serta strategi bersaingnya dengan tepat.

Adapun penentuan strategi bersaing hendaknya dilakukan dengan mempertimbangkan kepada besar dan posisi masing-masing perusahaan dalam pasar. Karena perusahaan yang besar mungkin dapat menerapkan stretegi tertentu yang jelas tidak bisa dilakukan oleh perusahaan kecil. Demikian pula sebaliknya, bukanlah menjadi sesuatu hal yang jarang terjadi bahwa perusahaan kecil dengan strateginya sendiri mampu menghasilkan tingkat keuntungan yang sama atau bahkan lebih baik dari pada perusahaan besar. 
Dengan memperhatikan dan mempertimbangkan semua hal diatas, maka dapat dipastikan perusahaan akan dapat menentukan dengan baik strategi pemasarannya serta strategi bersaingnya, untuk tetap maju dan berkembang di tengah-tengah persaingannya. Didalam penjelasan diketahui bagaimana suatu informasi dapat terbentuk dan menjadikan informasi sebagai sumber pengambil keputusan melalui alur dan struktur informasi, diharapkan sistem informasi manajemen mampu mengedepankan kualitas informasi yang dapat menilai apakah suatu informasi itu baik atau buruk jika diperoleh sehingga mampu memperbaiki dan meningkatkan sistem dan struktur manajemen informasi.

\section{DAFTAR RUJUKAN}

Utami, Christina Whidya. 2006. Manajemen Retail. Jakarta: Salemba Empat.

Utami, Christina Whidya. 2010. Manajemen Ritel: Strategi dan Implementasi Operasional Bisnis Ritel Modern di Indonesia Edisi: 2. Jakarta: Salemba Empat.

http://manajemen.7cara.com/125/struktur-elemen-teknologi-dan-tahapan-pengembangansistem- informasi-ritel-sim-ritel.htm

http://e-journal.uajy.ac.id/1666/2/1TI04868.pdf.

http://ginaaisyah92.blogspot.co.id/2012/06/bahasan-1-perencanaan-dan-manajemen.html. http://christine-sakura.blogspot.co.id/2012/06/bab-iperencanaan-manajemen-ritel.html. 